\title{
11
}

\section{From a Sharing Economy to a Platform Economy: Public Values in Shared Mobility and Gig Work in the Netherlands}

\author{
Martijn de Waal and Martijn Arets
}

\section{Introduction}

Initiatives in the sharing economy started to emerge in the Netherlands at the beginning of the 2010s, making the country one of the world's pioneers. At the beginning of the 2010s, many local initiatives such as Peerby (borrow tools and other things from your neighbours), SnappCar (peer-to-peer car sharing), and Thuisafgehaald (cook for your neighbours) launched that enabled consumers to share underused resources or provide services to each other. This was accompanied by a wide interest

\footnotetext{
M. de Waal $(\varangle)$

Civic Interaction Design Research Group, Amsterdam University of Applied Sciences, Amsterdam, the Netherlands e-mail: B.g.m.de.waal@hva.nl

M. Arets

Independent Platform Expert, Houten, the Netherlands e-mail: martijn@collaborative-economy.com
} 
from the Dutch media, zooming in on the perceived social and environmental benefits of these platforms. International commercial platforms such as Uber, UberPop, and Airbnb followed soon after. There have been various attempts to map the sharing economy platforms in the Netherlands. In 2018, the research project Deeleconomie in Nederland (The Sharing Economy in the Netherlands) found 250 different platforms. More than 200 of these have been documented in an online spreadsheet (Data aangemelde initiatieven, 2015). In terms of use, various studies have produced various results, depending on the exact definitions used of the sharing or platform economy. According to the Rathenau Institute (Frenken et al. 2017), 23\% of the Dutch population took part in the sharing economy in 2016, growing from 6\% in 2013. In 2019 Statistics Netherlands (CBS 2020) investigated the use of online platforms for ordering and exchanging goods or services and found that $58 \%$ of all Dutch citizens older than 12 had done so. This rose to the uptake of $80 \%$ in the age group $25-44$.

For the population at large, food delivery (used by $35 \%$ of the population above 12 years in 2019) was the most popular, followed by second-hand goods (32\%) and accommodation (20\%). Transport was less in demand, with $8 \%$ of the population using a platform to order car sharing, taxi services, or other transportation platforms (CBS 2020). According to the Deeleconomie Monitor 2018 (Hoekstra 2018), the largest growth is taking place in the use of commercial platforms providing services. Idealistic motives to take part in the sharing economy only play a limited role. Especially in the use of mobility platforms, ease of use and attractive pricing are the main drivers for usage (Hoekstra 2018). At the same time, there are still numerous more ideological-driven attempts to reorganise resource production and usage. For instance, in the Netherlands, in the past few years, many citizens have started to form energy cooperatives. Their number rose from 248 in 1015 to 582 in 2019, now servicing close to a quarter-million households (Schwenke 2019).

After their entrance to the market, the societal debate about the impact of these platforms also started to include the negative consequences. Early on, universities and national research and policy institutes took 
part in these discussions by providing definitions, frameworks, and analysis from a perspective of public values (Straathof et al. 2017; Frenken et al. 2017; Van Dijck et al. 2018; Van Eijk et al. 2015). In the last few years, the attention has shifted from the sharing economy to the much broader defined platform economy and its societal impact. In this chapter, this shift in the sharing economy and its societal repercussions will be illustrated by focussing on two discussions that have recently been waged around the sharing and platform economies in the Netherlands: shared mobility and gig work. Before we zoom in on these two domains, first, an overview will be given of the definitions of the sharing economy in the Netherlands and the most important issues brought up in the debate.

\section{Definitions and Debates of the Sharing Economy in the Netherlands}

In the Netherlands, the term 'deeleconomie' is a literal translation of the concept of the sharing economy (to share $=$ delen). It started to gain popularity in 2013 when mainstream media such as newspapers and magazines started to report on the phenomenon highlighting Dutch start-ups in this field, such as Peerby and SnappCar. Originally, the term was used to refer to platforms that allow citizens to make use of each other's goods as well as to platforms that offer various kinds of services.

Another term used early on in the debate is that of the collaborative economy, amongst others, by ShareNL—a Dutch organisation that explores and consults on the sharing economy. They define this as referring to 'economic systems of decentralised networks and marketplaces that unlock the value of underused assets by matching needs and haves, in ways that bypass traditional institutions' (ShareNL 2016).

Early on, the sharing economy was often discussed as part of the debate on smart cities as well as related to the discussion on the emergence of a 'participation' or 'energetic society' (de Waal and De Lange 2019; Hajer 2011) in which citizen collectives are empowered to self-organise around various issues of communal concern. In these interpretations, the term sharing referred to alternative forms of political 
and economic bottom-up organisation. More formal definitions started to appear around 2015 when the success of various platform services started to lead to questions with regard to regulation. In order to help policymakers discern between informal citizen initiatives and commercial services belonging to the formal economy, Koen Frenken, Toon Meelen, Martijn Arets, and Pieter van de Glind narrowed down the definition of the sharing economy as 'consumers granting each other temporary access to under-utilised physical assets ('idle capacity'), possibly for money' (Frenken et al. 2017). This definition has three elements. Primarily, the sharing economy concerns transactions between consumers ('consumerto-consumer' also referred to as 'peer-to-peer'). Secondly, the transactions involve 'temporary accesses to an asset'. Thirdly, it involves assets and not services. Later on, in the debate, the term gig economy or 'kluseconomie' has been introduced to refer to platforms that provide access to services. In the gig economy, consumers provide services for one another rather than providing access to goods (Frenken et al. 2017).

Initially, the sharing economy was hailed as a positive force in society, as it was thought to contribute to both social and economic capital. It was also seen as a positive force for the environment. Sharing resources, it was hoped, would lead to a smaller ecological footprint, and the peerto-peer relations enabled by the platforms were hoped to contribute to improving social relations at the neighbourhood level. In that vein, the sharing economy was also embraced as an opportunity to brand a city and stimulate local innovation. The city of Amsterdam, for instance, started to promote itself as a European capital of innovation that is based on the 'Amsterdam-approach.' This means an approach to smart cities that is not based on technology per se but rather seeks alliances with civil society and is organised around societal challenges. In this framework, the city has adopted an action plan for the sharing economy that consists of five main actions: Stimulating the sharing economy; Leading by example; A sharing economy for all Amsterdam citizens; Rules and regulations; and Putting Amsterdam on the map as a Sharing City (ShareNL 2016). In Amsterdam, this programme so far has led to a small number of experiments.

Yet already in 2017, the more critical views started to appear in the debate, as epitomised by the newspaper headline 'de deeleconomie heeft 
zijn onschuld verloren' (the sharing economy has lost its innocence) (Hermanides 2017). The emergence of UberPop and Uber led to discussions about the regulation of labour. Platforms such as Airbnb started to have an effect on the livability in cities such as Amsterdam, tying debates about the sharing economy to broader debates about the negative consequences of tourism. Especially Amsterdam has joined the ranks of cities such as Barcelona and Venice, in which local residents feel overwhelmed by masses of tourists who - in the views of these locals - are taking over their city. In Amsterdam, the city council has decided that residents can only rent out their houses and apartments for a maximum of 30 days a year. So far, enforcement of this rule has been problematic as Airbnb does not want to provide data about rentals to the local government.

In the past few years, discussions on the sharing or collaborative economy have become part of broader discussions about the platform economy. Platforms are now seen as possibly new institutional forms becoming part of the economy, possibly undermining traditional regulation and social arrangements. In a report to the Dutch government, TNO (Nederlandse Organisatie voor Toegepast Natuurwetenschappelijk Onderzoek; Netherlands Organisation for Applied Scientific Research) defined the term 'platform' as 'a (technological) basis for delivering or aggregating services/content from service/content providers to endusers' (Van Eijk et al. 2015). Their examples include not only sharing economy platforms but also entertainment and e-commerce platforms such as Netflix, Bol.com, and Facebook. In a recent study from the Social and Economic Council of the Netherlands (SER 2020, p. 16), platforms are defined as intermediaries that 'organise the coordination of supply and demand for services and commodities.' In addition, Van Dijck et al. (2018, p. 4) defined a platform as 'a programmable digital architecture designed to organise interactions between users- not just end-users but also corporate entities and public bodies.' What many of these definitions have in common is that they focus on the role of (sharing) platforms as intermediaries and that through their particular design (interface, algorithms, business models, etc.) govern the interactions between third parties such as users and service providers. Whereas originally, the public debate was mostly focussed on the functions of these platforms (they allow sharing and collaborating in new ways), 
more recently, the exact mechanisms of their intermediation and their governmentalities have come into full scrutiny, especially in relation to regulation by governments.

Various academic studies, as well as advisory councils of the Dutch government, started to research platforms from a framework of institutions, arguing that platforms could be understood as a new institutional form of organising economic, social, and cultural activities with its own logic. Increasingly, platforms are seen as de facto private regulators, disrupting the balance between the institutional logics of the market, corporation, and the regulatory powers of the state. Platforms provide opportunities for individuals to trade services but may also entail risks for these individuals as well as their customers and violate their rights or endanger other public values. Preventing these risks through public regulation and enforcement poses huge challenges to public regulatory authorities, as existing legal powers and instruments fall short in this new context (Frenken and Van Slageren 2018; Frenken et al. 2017; Ranchordas 2015). Public values and public interests were introduced as a lens to analyse and regulate the platform economy in studies such as The Platform Society and A Fair Share: Safeguarding Public Interests in the Sharing and Gig Economy (Frenken et al. 2017; Van Dijck et al. 2018). Debates have centred amongst others on transparency and accountability of platforms, data ownership and data portability, and issues related to algorithmic governance in platforms and the need for algorithmic transparency. Two instantiations of the sharing economy are particularly insightful to highlight discussions about the sharing economy in the Netherlands: shared mobility and the gig economy.

\section{Shared Mobility: Contributing to a More Sustainable City, or Usurping Public Space and Undermining Worker's Rights?}

Discussions on shared mobility in the Netherlands are tightly connected to the broader debates about the sharing economy. On the one hand, shared mobility and especially car sharing is seen as a possible contribution to a greener and more sustainable economy. On the other hand, 
negative consequences have been discussed with regard to public values such as consumer and worker protections as well as qualities of public space. Three forms of shared mobilities have been debated widely in the Netherlands: bike-sharing, car sharing, and ride-hailing.

\section{Bike-Sharing and Electric Scooters}

Bike ownership in the Netherlands has been one of the highest in the world. Its 17 million inhabitants own 23 million bikes. Already 25\% of daily mobility takes place by bike (Harms and Kansen 2018). Since 2003, the OV-fiets (Public Transport Bike), a bike rental scheme at Dutch public transit stations, has grown increasingly popular. With their public transport chip card, users of public transport can pick up and return a bike at a train station or bus terminal for a small fee (currently 3.85 euro for $24 \mathrm{~h}$ ). Usage has grown from around 100,000 rides in 2004 to more than five million in 2019 (OVPro 2019). Private lease constructions for bike usage have also become more popular in the last few years. The Dutch start-up Swapfiets is now active in four countries and has reported 200,000 customers leasing their bikes (De Ondernemer 2020).

Combined, these developments have left less room for the docked and dockless public bike-sharing schemes that have been set up in some other countries. Still, a number of providers have started experiments in the Netherlands. For instance, Mobike has distributed its dockless bikes in Rotterdam and Delft. Flickbike introduced between 4000 and 6500 bikes in Amsterdam. Especially in Amsterdam, this led to lots of discussions about the negative impact of the parked and abandoned bikes in public spaces, and hence the desirability of commercial companies usurping public space for their services. In 2017 the City of Amsterdam, after an injunction against Flickbike, the city removed all the bikes on the ground of a regulation prohibiting commercial service provisions in public space. In 2020 the City allowed four new small-scale experiments for a total of 1400 (partly electric) bikes (Fietsberaad Crow 2020).

So far in the Netherlands, electric scooters such as those offered by Lime and Bird have been deemed illegal. A number of cities have started to experiment with electric motor scooters through companies such as 
Go Mobility and Felyx. The national government has taken an interest in bike-sharing systems as part of a larger mobility policy, in which bike-sharing can play a role for first and last-mile solutions in broader Mobility as a Service provision. Although there are yet no figures available that show the long-term impact of bike-sharing, it is expected that each new shared bike could contribute to $0.1-0.6$ people avoiding rush hour (car) traffic per day, and as such contribute to $\mathrm{CO}_{2}$ reduction, which is calculated at around $0.37-2.22 \mathrm{~kg}$ (Ministerie van Verkeer en Waterstaat 2020).

\section{Car Sharing}

Similar hopes have been expressed around the development of car sharing systems. In 2017, various parties signed a so-called 'Green Deal' (a covenant between various parties, including (local) governments in the Netherlands) about car sharing. Parties involved included car sharing providers, insurers, municipalities, environmental organisations, and the ministries of Economic Affairs and Infrastructure and Environment. The goal of this programme was to stimulate car sharing and contribute to a better environment. In the first Green Deal, the parties committed to developing a total of 100,000 shared cars by 2018. Although this number was not realised, there was enough interest to renew the commitment in 2018, now aiming for 100,000 shared cars and 700,000 users by 2021. Parties involved have projected that participants who exchange their regular car for a shared one contribute to a reduction of between eight and $13 \%$ of their $\mathrm{CO}_{2}$ emissions. In addition, the goal is to free up parking places in cities and make these spaces available for green spaces and recreation (RVO 2018). By the end of 2020, the ambition with regard to the number of users had already been met, whereas the number of available cars had grown to 64,000. Part of the new interest has been ascribed to the COVID-19 crisis. As a result of the crisis, citizens wanting to avoid public transport turned to car sharing, whereas commuters no longer needing their car to travel to work could more easily offer these through platforms (Kennisplatform Crow 2020). 
The interest in car sharing is accompanied by the emergence of experiments around 'Mobility as a Service' that include various modalities of transport in a single platform. In the Netherlands, seven national pilots have been set up in different cities across the country. International initiatives such as Whim have announced plans to enter the market in the Netherlands, but so far have not implemented these. Looking at developments in car sharing, a wide variety of options are now available (Münzel et al. 2017). Most cars are available through peer-to-peer services, with the Dutch start-up SnappCar being one of the pioneers in this field worldwide. However, in the last few years, more offerings have appeared in the product-service economy, with various companies offering subscription services or private lease constructions for consumers to make use of their fleets. In line with this development, Snapcar itself has also started offering private lease constructions to customers, who then make their cars available for sharing through the SnappCar platform. In addition, there is a rise in community car sharing, in which local groups of residents manage small fleets of cars (Arets 2019).

Experts expect that commercial services will grow in popularity due to their ease of use, yet they still see a future for peer-to-peer models of sharing. These will especially have a future in renting out 'specials' such as old-timers, convertibles, or campers (Arets 2020). In general, it can be said that the sharing economy in the Netherlands has become more commercial and professional in character, where peer-to-peer sharing between consumers is increasingly meeting alternatives offered by commercial services.

\section{Ride-Hailing}

This commercial perspective is especially prominent in the third domain of shared mobility: ride-hailing. Whereas in car sharing, consumers use a car offered by a peer or a company, ride-hailing concerns mobility services in which the consumer is a passenger, either sharing a ride with another consumer or making use of a commercial mobility service platform such as Uber. The latter has tried to disrupt the Dutch market for taxi services by introducing the peer-to-peer service Uberpop in the 
Netherlands in 2014. At the time, the company claimed it did not need to comply with taxi regulations, as the drivers were private individuals offering a peer-to-peer service. After it was fined several times, the company shut down the service in 2015 and, in the end, received a 2.3 million euro fine for its illegal activities in 2019 (Van de Weijer 2019).

The rise of commercial ride-hailing platforms has led to numerous debates about the safeguarding of public values, such as protecting consumer safety and worker's rights. Uber made headlines in late 2018 and early 2019 after a number of deadly accidents were caused by Uber drivers (e.g. Van Bergeijk 2018). Now the debate focussed on the responsibility of organising shared mobility. Does the platform itself have a responsibility, or does it lie with the individual service providers who operate through the platform? Critics of the company claimed that Uber's business model stimulates drivers to make long hours on the road, cruising around the city looking for a fare and thus compromising safety (e.g. Kruyswijk 2018). In reaction, the city of Amsterdam and Uber started discussions in the Uber Taskforce, leading to a social charter in which Uber pledges to improve safety, amongst others, by introducing in the future facial recognition technologies to make sure drivers do not mislead systems that check on maximum driving times. Uber will also start sharing data with the city of Amsterdam to make the practises of its drivers more transparent. With these discussions, another aspect of the sharing economy has come into play: that of labour relations and the gig economy. The next session will further elaborate on the debates around the organisation of labour and the safeguarding of public values that have arisen in the Netherlands in the past few years.

\section{The Gig Economy in the Netherlands: New Economic Opportunities, or Deterioration of Workers' Rights?}

As shown in the previous paragraph, discussions about Uber do not only address the organisation of shared mobility but have started to include discussions about the organisation of labour in the platform economy. 
These are part of a broader debate about the gig economy and the organisation of platformised work. Since the sharing economy in the Netherlands was quickly delineated with a narrow definition referring to consumers making use of each other underused resource, it was clear from the start that (paid) labour could not be placed under the umbrella of the sharing economy. With the gig economy, a separate definition was minted for the supply of paid labour services through platforms. It was defined as follows: 'The gig economy consists of freelancers who perform one-off physical tasks (jobs), where the assignment is paid for and is created via an online platform (a website or an app)'. Although there is consensus about the definition, in practise, providers do not have the status of a freelancer in all cases. For example, providers on platforms that mediate between the supply and demand of services in and around the home (babysitting, home cleaning, and homework supervision) often work under the Dutch 'Regulations for Services at Home.' A scheme that indemnifies the consumer as an employer against certain responsibilities, but in principle, has little impact on the position of the provider.

\section{Size and Shape of the Gig Economy: Mostly Facilitating Low-Skilled Labour}

Various studies have made an effort to map the gig economy in the Netherlands. For example, in an online survey of 2125 Dutch adults, a representative for all Dutch citizens aged 16-70 years, conducted by the University of Hertfordshire and Ipsos MORI, in 2016, 18\% indicated that they had at some point tried to find work through gig economy platforms. About one in eight (12\%) of the respondents indicated that they made money this way at some point (Dhondt et al. 2020). SEO Economic Research conducted a sample of more than 5440 people in 2019 and concluded that a total of $1.7 \%$ of the working population has been or has ever been active as a gig worker. A large part $(1.2 \%$ of the working population) indicated that they have been active as a gig worker in the past year (Ter Weel et al. 2020).

In 2020 independent research organisation TNO made an overview of the gig economy landscape in the Netherlands. For this, they used, 
amongst other things, a dataset set up by Martijn Arets as input for the Dutch website Platformwerk (2020). As of December 2020, this website listed 82 platforms in the Netherlands for various forms of work, from cleaning and construction to creative and legal jobs. TNO analysed the platforms based on skills level for the execution of the work (Pesole et al. 2018). They use the International Standard Classification of Occupations ISCO 2008 classification 2 according to a professional level. They concluded that 23 out of 66 platforms offered opportunities to low-skilled workers. Examples are food delivery, cleaning, freight transport, and walking dogs. Eighteen platforms offered jobs that require medium-level skills such as construction, tourism, and health care. Only five platforms provided opportunities for high-skilled work such as IT, business services, education, the legal profession (Verbiest et al. 2020).

\section{Impact on Labour Conditions: Enabling Easier Access to Paid Work at the Risk of Increasing Precarity}

The potential of the gig economy can be significant, according to a survey by the ING (Internationale Nederlanden Groep; International Netherlands Group) Economic Agency. In this survey, the authors predict that platforms will take over between $20 \%$ and $70 \%$ of the temporary employment sector in 10 years' time. This depends on the further development of technology and the complexity of regulations (Blom 2018). The fact that this prediction has yet to come true is endorsed in 2020 by the SER (Social and Economic Council), an institute that advises the Dutch Government and Parliament on social and economic policy. SER President Mariëtte Hamer, on the basis of an exploration of 'Platform Economy and Work.' states that 'the insane tension that the platform economy would create on the labour market' has not yet materialised (Sociaal Economische Raad 2020). The SER report underlines the advantages of gig economy platforms that bring together supply and demand for work. The platforms enable access to paid work, even if that is normally difficult due to a lack of formal education. They offer opportunities for entrepreneurs to generate profit and increase choice and convenience for consumers (Sociaal Economische 
Raad 2020). At the same time, the SER warns against the risks of dependence on the platform, the lack of certainty and perspective and the risk of low rates and long hours.

These opportunities and uncertainties are also endorsed by researcher Niels van Doorn of the University of Amsterdam. He has researched meal deliverers and home cleaners in the cities of New York, Amsterdam, and Berlin (Platform Labor 2021). One of his conclusions is that a lot of the work organised through these platforms was taken up by immigrants. Without a residence permit, they often end up in jobs in construction, cleaning, food delivery, or restaurants. Platforms are an easy entry into these work fields, as usually, a few questions are asked. Interviewed in the book Platform Revolution (Arets 2020, p. 126), he states: 'Platform work is usually the best option, as they can get started quickly, and quickly paid, and generally few questions are asked, so they need little to worry about their lack of language skills being higher than what they would earn elsewhere-especially at the outset, due to the fact that platform companies use venture capital keep wages artificially high in markets with very thin margins.' Van Doorn concludes that platform work initially seems to be a great opportunity for many migrants. However, in due time they find that there are many risks involved and that their position is precarious. They get paid less, lose their income when involved in an accident or when they become ill. Sometimes they are thrown off the platform, or they get problems with the tax authorities when they do not have their tax affairs in order. Without alternatives, they have little choice and tend to absorb these risks for as long as possible (Arets 2020).

This precarity came once more to the light during the recent COVID19 crisis. At Helpling, a platform broker for home cleaning services, already $40 \%$ of the jobs were cancelled during the first week of the lockdown in the Netherlands (Hueck 2020). This figure was expected to rise quickly to $50-60 \%$. Also, Uber drivers complained about a huge decline in work and hardly covered their costs. Uber reported a fall in demand of 70 to $80 \%$ during that first period. A similar setback was noticed by drivers not working through an app. Research shows that $71 \%$ of the cab drivers in Amsterdam expect to quit within a year; amongst Uber drivers, this rate is as high as $76 \%$ (de Ruiter 2020). 
Special attention in many of the debates of the platform economy has been paid to the role of platform organisers as private regulators (Boudreau and Hagiu 2009). They have become de facto private regulators and market superintendents who are able to unilaterally set the rules for interaction and mediation on their platforms. This is all the more problematic as platforms continuously change their terms of engagement and mechanisms. Platforms continuously monitor their internal mechanisms and output and adjust many of their features on an ongoing basis. They are able to quickly change the rules and conditions of their intermediation, adding or deleting features or new aspects to their interfaces.

Another issue at stake is data portability. As reputation scores are an important aspect in the matchmaking between service providers and potential customers, it is hard for service workers to shift their business to a new platform as they would have to start all over again building up their reputation. This means they have a weak position negotiating terms with platforms and makes it difficult to leave once; for instance, platforms change their terms or their fee. To investigate how experience gained via a gig economy platform can contribute to better job opportunities, Martijn Arets started an exploration and pilot with six platforms, supported by various partners such as the Dutch and Swedish Employment Services, a large trade union and the Ministry of Economic Affairs and Climate (Kluspaspoort 2021). One of the issues explored is how experienced and reputation profiles can be converted into digital CV that can be shared across platforms.

These discussions show that the development of the gig economy in the Netherlands is still in full swing. In the beginning, the focus was mainly on platforms that serviced individual consumers as their end customers. More recently, the debate has shifted to platforms that cater to businesses and have started to compete directly with temping agencies. More and more government departments have started to research the gig economy. For example, the Ministry of Finance initiated a study into tax collection via platforms in 2020 (Rijksoverheid 2020). This indicates that more and more stakeholders believe that platforms will continue to play an important role in bringing together supply and demand for 
labour in the future. The aim now is to enhance positive effects and prevent risks.

\section{Summary}

The Netherlands was an early adopter of the sharing economy. Whereas initially, the sharing economy was framed from a perspective of social relations and its potential positive impact on society, increasingly, it is now seen from an economic perspective. Services themselves have commercialised with commercial companies offering, for instance, mobility in a product-service economy through platforms, although there are also some interesting counter developments. In car sharing, community car sharing between groups of local residents has grown increasingly popular, and energy communities consisting of citizens who collaboratively produce and consume their own energy, both pointing to the emergence of citizen organised resource communities.

In general, though, the debate has turned from a sharing and collaborative economy to a platform economy. With that shift, platforms are now seen as new factors in the organisation of the economy at large as well as the provision work, acting as private regulators that set the conditions for interaction and mediation in many markets. Debates are now focussing on the effects of this on public values. Platforms may still positively contribute to these, for instance, by greening mobility or by making it easier for people to find paid work. Yet, at the same time, it is feared that the commercialisation and extractive nature of some of the main platforms could lead to precarious working conditions. The fact that many of these commercial platform operators position themselves merely as mediators and as having no responsibility themselves for the sector they operate in adds to fears that they are offloading responsibility for issues such as consumer safety or workers' rights to society at large. Meanwhile, governments at various levels are trying to get a grip on these developments, as in many cases, they have not yet found the right answer to regulate these platforms as, for instance, platforms such as Airbnb have refused to cooperate with local regulation. This struggle for the provision 
of public values and the regulation of and within platforms is likely to remain an important theme in the years to come.

\section{References}

Arets, Martijn. 2019. 'Het Einde van de deeleconomie (The End of the sharing Economy).' Platformrevolutie (Platform Revolution), 19 January 2019. http://rev.vu/7PDV36.

Arets, Martijn. 2020. Platformrevolutie Hoe platformen als Amazon en Apple de maatschappij en economie veranderen (Platform Revolution. How Platforms Such as Amazon and Apple Change Society and the Economy). Amsterdam: Boom.

Blom, Marieke. 2018. Platformen kunnen arbeidsmarkt drastisch veranderen (Platforms Could Drastically Change the Labor Market). Amsterdam: ING Economisch Bureau.

Boudreau, Kevin, and Andrei Hagiu. 2009. 'Platform Rules: Regulation of an Ecosystem by a Private Actor.' In Platforms, Markets and Innovation (pp. 163-191), edited by Annabelle Gawer. Cheltenham, Northampton, MA: Edward Elgar.

CBS (Statistics Netherlands). 2020. 'Bijna 3 op de 5 Nederlanders maakte in 2019 gebruik van online platforms (Nearly 3 in 5 Dutch People Used Online Platforms in 2019).' CBS.nl. https://www.cbs.nl/en-gb/news/2020/ 14/nearly-3-in-5-dutch-people-used-online-platforms-in-2019. Accessed April 3, 2020.

De Ondernemer. 2020. 'Verdubbeling cijfers Swapfiets mede dankzij internationale expansie (Swapfiets Grows 100\%, Partly Due to Its International Expansion).' De ondernemer.nl. https://www.deondernemer.nl/mobiliteit/ver dubbeling-groeicijfers-swapfiets 2295356. Accessed June 22, 2020.

de Ruiter, Marieke. 2020. 'Crisis toont kwetsbare positie platformwerker: 'Hoofdpijn, veel hoofdpijn' (Crisis Shows Preciarious Position Gig Worker: "Headaches, Lots of Headaches").' de Volkskrant. https://www.volkskrant. $\mathrm{nl} /$ economie/crisis-toont-kwetsbare-positie-platformwerker-hoofdpijn-veelhoofdpijn $\sim$ bccd205c/?utm_campaign=Platform\%20Talks\&utm_medium= email\&utm_source=Revue\%20newsletter. Accessed June 4, 2020.

de Waal, Martijn, and Michiel De Lange. 2019. 'Introduction-The Hacker, the City and Their Institutions: From Grassroots Urbanism to Systemic 
Change.' In 1 BT-The Hackable City, edited by Michiel De Lange and Martijn de Waal. Singapore: Springer. https://doi.org/10.1007/978-981-132694-3.

Dhondt, Steven, Ursula Huws, E. Zander, and Catalin DragonimerescuGaina. 2020. Nieuwe schatting van de omvang van de Nederlandse Gig Economie (New Estimation of Size of Dutch Gig Economy). Leiden: TNO. https://repository.tno.nl//islandora/object/uuid:68d7f02fd24b-458b-bb3e-6d69cd6a5da2.

Fietsberaad Crow (National Knowledge Center Biking Policy for Dutch Governments). 2020. 'Amsterdam kiest vier aanbieders van deelfietsen (Amsterdam Chooses Four Providers for Bikesharing).' https://www.fietsberaad. $\mathrm{nl} /$ Kennisbank/Amsterdam-kiest-vier-aanbieiders-van-deelfietsen. Accessed August 26, 2020.

Frenken, Koen, and Jaap Van Slageren. 2018. 'Kluseconomie is meer dan Uber en Deliveroo (The Gig Economy Is More than Uber and Deliveroo).' Economisch Statistische Berichten. https://esb.nu/esb/20047499/klusec onomie-is-meer-dan-uber-en-deliveroo. Accessed 20 December 20, 2018.

Frenken, Koen, Arnoud Van Waes, Magda Smink, and Rinie Van Est. 2017. A Fair Share: Safeguarding Public Interests in the Sharing and Gig Economy. The Hague: Rathenau Instituut. Available at: https://www.rathenau.nl/en/ publication/fair-share\%C2\%A0\%E2\%80\%93-safeguarding-public-intere sts-sharing-and-gig-economy.

Hajer, Maarten. 2011. De Energieke Samenleving. Op Zoek Naar Een Sturingsfilosofie Voor Een Schone Economie. Den Haag: Planbureau voor de Leefomgeving.

Harms, Lucas, and Maarten Kansen. 2018. Fietsfeiten (Biking facts). Den Haag: Kennisinstituut voor Mobiliteitsbeleid (Knowledge Institute for Mobility Policy).

Hermanides, Elisa. 2017. 'De deeleconomie heeft zijn onschuld verloren (The Sharing Economy Lost Its Innocence).' Trouw. https://www.trouw.nl/ nieuws/de-deeleconomie-heeft-zijn-onschuld-verloren-be430509/. Accessed September 2, 2017.

Hoekstra, Hans. 2018. 'taat van de Deeleconomie in Nederland (State of the Sharing Economy in the Netherlands).' Newcom Research \& Consultancy. https://www.newcom.nl/2018-deeleconomie. Accessed March 27, 2018.

Hueck, Hella. 2020. 'De werkster is ineens niet meer nodig (The Cleaner Is No Longer Needful).' Het Financiele Dagblad. https://fd.nl/ondern emen/1338913/de-werkster-is-ineens-niet-meer-nodig?utm_campaign=Pla 
tform\%20Talks\&utm_medium=email\&utm_source=Revue\%20newsletter. Accessed March 23, 2020.

Kennisplatform Crow. 2020. 'Met 730.000 deelautogebruikers is het doel overtroffen (With 730.000 Users of Car-Sharing Systems, the Goal Has Been Exceeded).' CROW (Technology Platform for Transport Infrastructure and Public Space). https://www.crow.nl/over-crow/nieuws/2020/okt ober/met-730-000-deelautogebruikers-is-het-doel-overtro. Accessed October 29, 2020.

Kluspaspoort. 2021. www.kluspaspoort.nl. Accessed June 14, 2021.

Kruyswijk, Marc. 2018. 'Uber opnieuw in opspraak: "Het is wachten op de volgende dode".' Het Parool. https://www.parool.nl/nieuws/uber-opnieuwin-opspraak-het-is-wachten-op-de-volgende-dode-b942d937/. Accessed December 5, 2018.

Ministerie van Verkeer en Waterstaat. (Ministry of Transport and Public Works). 2020. 'Factsheet Deelfietssystemen (Fact Sheet Bike Sharing Systems).' https://rwsduurzamemobiliteit.nl/kennis-instrumenten/toolbox-sli mme-mobiliteit/fiets/factsheet-deelfietssystemen/. Accessed December 10, 2020 and June 14, 2021.

Münzel, Karla, Wouter Boon, Koen Frenken, and Taneli Vaskelainen. 2017. 'Carsharing Business Models in Germany: Characteristics, Success and Future Prospects.' Information Systems and e-Business Management 16: 271291.

OVPRO. 2019. 'Eén miljoen extra OV-fietsritten afgelegd in 2019 (One Million Extra Rides on Public Transport Bikes in 2019).' OVPro.nl. https:// www.ovpro.nl/innovatie-2/2019/12/18/een-miljoen-extra-ov-fietsritten-afg elegd-in-2019/?gdpr=accept\&gdpr=accept. Accessed December 12, 2019.

Pesole, Annarosa, Maria Cesira Urzí Brancati, Enrique Fernández-Macías, Federico Biagi, and Ignacio González Vázquez. 2018. Platform Workers in Europe. Luxembourg: Publications Office of the European Union.

Platformwerk. 2020. 'Alle Kluseconomie Platformen (All Gig Economy Platforms).' www.platformwerk.nl. Accessed December 10, 2020.

Platform Labor. 2021. www.platformlabor.net. Accessed June 14, 2021.

Ranchordas, Sofia. 2015. 'Innovation Experimentalism in the Age of the Sharing Economy.' Lewis \& Clark Law Review 871-924. https://doi.org/ 10.1525/sp.2007.54.1.23.

Rijksoverheid. 2020. 'Bouwstenen voor toekomstig belastingstelsel gepresenteerd. (Building Blocks for New Tax System Presented).' Rijksoverheid.nl. https://www.rijksoverheid.nl/actueel/nieuws/2020/05/18/bouwstenen-voortoekomstig-belastingstelsel-gepresenteerd. Accessed May 18, 2020. 
RVO Rijksdienst voor Ondernemend Nederland (Netherlands Enterprise Agency). 2018. 'Green Deal Autodelen II (Green Deal Car Sharing II).' https://www.greendeals.nl/green-deals/green-deal-autodelen-ii. Accessed December 10, 2020.

Schwenke, Anne Marieke. 2019. De Lokale Energie Monitor (The Local Energy Monitor). HIER opgewekt and RVO. https://www.hieropgewekt.nl/uploads/ inline/Lokale\%20Energie\%20Monitor\%202019_DEF_28-11-2019_1.pdf

ShareNL. 2016. 'Welcome to the Collaborative Economy Ecosystem.' https:// www.sharenl.nl/welcome-to-the-collaborative-economy-ecosystem. Accessed December 10, 2020.

SER Sociaal Economische Raad. 2020. Hoe werkt de platformeconomie (How Does the Platform Economy Work?). Den Haag: Sociaal Economische Raad (The Social and Economic council of the Netherlands).

Straathof, Bas, Sander van Veldhuizen, and Michiel Bijlsma. 2017. Platforms Veranderen de Wereld. Den Haag: CBS.

Ter Weel, Bas, Justus van Kesteren, and Siemen van der Werff. 2020. Meting kluseconomie (Measuring the Gig Economy). Amsterdam: SEO Economisch Onderzoek.

Van Bergeijk, Jeroen. 2018. 'Uber-chauffeur voor rechter na dodelijk ongeval: 'Een zaak met alleen maar verliezers' (Uber-Driver Appears in Court After Deadly Accident: "A Case With Only Losers.”' De Volkskrant. https://www. volkskrant.nl/nieuws-achtergrond/uber-chauffeur-voor-rechter-na-dodelijkongeval-een-zaak-met-alleen-maar-verliezers-bfc00ea9/. Accessed Oktober 31, 2018.

Van Dijck, José, Thomas Poell, and Martijn de Waal. 2018. The Platform Society: Public Values in a Connected World. New York, NY: Oxford University Press.

Van Eijk, Nico, Ronan Fahy, Harry Van Til, Pieter Nooren, Hans Stokking, and Hugo Gelevert. 2015. Digital Platforms: An Analytical Framework for Identifying and Evaluating Policy Options. The Hague: TNO. http://www. ivir.nl/publicaties/download/1703.

Verbiest, Sarieke, Hardy Van de Ven, and R. E. C. Van Den Bergh. 2020. Platformarbeid in kaart brengen (Mapping gig work). Leiden: TNO.

Van de Weijer, Bard. 2019. 'Boete van 2,3 miljoen euro wegens UberPop; Uber zegt leven te hebben gebeterd. de Volkskrant. https://www.volksk rant.nl/nieuws-achtergrond/boete-van-2-3-miljoen-euro-wegens-uberpopuber-zegt-leven-te-hebben-gebeterd-b0a7ff5c/\#:-:text=Taxidienst $\% 20 \mathrm{U}$ ber $\% 20$ moet $\% 202 \% 2$ C3,taxi $\% 2$ C $\% 20$ zonder $\% 20$ de $\% 20$ benodigde $\% 20 v$ 
ergunningen.\&text=Het $\% 20$ bedrijf $\% 20$ heeft $\% 20$ hiermee $\% 20$ de $\% 20$ wet $\%$ 20overtreden. Accessed March 8, 2019.

\section{Suggested Readings}

Arets, Martijn. 2020. Platformrevolutie Hoe platformen als Amazon en Apple de maatschappij en economie veranderen (Platform Revolution. How Platforms Such as Amazon and Apple Change Society and the Economy). Amsterdam: Boom.

Dhondt, Steven, Ursula Huws, E. Zander, and Catalin DragonimerescuGaina. 2020. Nieuwe schatting van de omvang van de Nederlandse Gig Economie (New Estimation of Size of Dutch Gig Economy). Leiden: TNO. https://repository.tno.nl//islandora/object/uuid:68d7f02fd24b-458b-bb3e-6d69cd6a5da2.

Hajer, Maarten. 2011. De Energieke Samenleving. Op Zoek Naar Een Sturingsfilosofie Voor Een Schone Economie. Den Haag: Planbureau voor de Leefomgeving.

Pesole, Annarosa, Maria Cesira Urzí Brancati, Enrique Fernández-Macías, Federico Biagi, and Ignacio González Vázquez. 2018. Platform Workers in Europe. Luxembourg: Publications Office of the European Union.

\section{Relevant Websites}

Deeleconomie in Nederland. http://www.deeleconomieinnederland.nl.

Platformwerk. http://www.platformwerk.nl.

Platform Labor. http://www.platformlabor.net.

ShareNL. http://www.sharenl.nl. 
Open Access This chapter is licensed under the terms of the Creative Commons Attribution 4.0 International License (http://creativecommons.org/ licenses/by/4.0/), which permits use, sharing, adaptation, distribution and reproduction in any medium or format, as long as you give appropriate credit to the original author(s) and the source, provide a link to the Creative Commons license and indicate if changes were made.

The images or other third party material in this chapter are included in the chapter's Creative Commons license, unless indicated otherwise in a credit line to the material. If material is not included in the chapter's Creative Commons license and your intended use is not permitted by statutory regulation or exceeds the permitted use, you will need to obtain permission directly from the copyright holder.

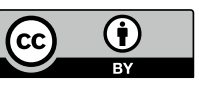

